Jurnal Info Kesehatan

Vol 16, No.2, Desember 2018, pp. 197-213

P-ISSN 0216-504X, E-ISSN 2620-536X

Journal DOI: https://doi.org/10.31965/infokes

Website: http://jurnal.poltekeskupang.ac.id/index.php/infokes

RESEA R C H

Open Access

\title{
Studi Faktor-Faktor Yang Berhubungan Dengan Kejadian Penyakit Kusta Pada Wilayah Kerja Puskesmas Bakunase Kota Kupang Tahun 2017
}

\author{
Edwinandro V. Salju \\ Alumni Pascasarjana Magister Ilmu \\ Kesehatan Masyarakat Universitas Nusa \\ Cendana.
}

Email: edwinsalju@gmail.com

\author{
Muntasir, Luh Putu Rulianti \\ Program Studi Kesehatan Masyarakat, \\ Fakultas Kesehatan Masyarakat, Universitas \\ Nusa Cendana.
}

Email: mutansir@staf.undana.ac.id Email:ruliatiluhputu@yahoo.com

Jl. Adisucipto, Lasiana, Pasir Panjang, Kupang, Nusa Tenggara Timur - Indonesia. 85000

\begin{abstract}
Abstrak
Kusta adalah penyakit infeksi kronis yang masih menjadi masalah kesehatan masyarakat di Indonesia. Terjadi peningkatan jumlah kasus kusta baru di wilayah kerja Puskesmas Bakunase Kecamatan Kota Raja Kota Kupang menunjukkan tingginya risiko angka penularan penyakit kusta di masyarakat. Tujuan penelitian ini untuk mengetahui Faktor yang Berhubungan dengan Kejadian Kusta di Wilayah Kerja Puskesmas Bakunase Kota Kupang. Jenis penelitian adalah survey analitik dengan studi cross-sectional dengan metode Total sampling. Sampel dalam penelitian ini sebanyak 33 orang yang merupakan penderita kusta. Karakteristik responden terbanyak diketahui yaitu umur $>15$ tahun, berjenis kelamin Pria, Pekerjaan Berisiko, Perpendidikan rendah, pendapatan sosial ekonomi <UMP, tingkat pengetahuan rendah, tingkat Kebersihan buruk, tingkat riwayat Kontak $>2$ tahun dan tingkat Kepatuhan Minum obat baik. Hasil anahsis bivariat menunjukkan terdapat hubungan signifikan antara Pekerjaan $(\mathrm{P}=0,026)$, pendidikan $(\mathrm{P}=0,026)$, sosial ekonomi $(\mathrm{P}=0,032)$, pengetahuan $(P=0,027)$, kebersihan $(p=0,012)$, dan riwayat kontak $(\mathrm{p}=0,003)$. terhadap kejadian penyakit kusta. Simpulan penelitan, pekerjaan, pendidikan, sosial ekonomi, pengetahuan, kebersihan dan riwayat kontak mempengaruhi kejadian kusta sedangkan umur, jenis kelamin dan kepatuhan minum obat tidak mempengaruhi kejadian kusta pada Wilayah Kerja Puskesmas Bakunase.
\end{abstract}

Kata Kunci: Kusta, Faktor Yang Mempengaruhi Kejadian Kusta, Bakunase. 


\title{
Description of Factors Connected with Loss Events in the Working Region of Bakunase Community Health Center Kupang City in 2017
}

\begin{abstract}
Leprosy is a chronic infection that remains a public health problem in Indonesia. An increase in the number of new cases of leprosy in the work area of Bakunase Health Center, Kupang City, shows the high risk of leprosy transmission rate in the community. The purpose of this research is to know Factor Relating to Leprosy in Working Area of Bakunase Health Center of Kupang City. The type of research is analytic survey with cross-sectional study with Total sampling method. Samples in this study as many as 33 people who are lepers. Characteristics of respondents most known namely age >15 years, male, work at Risk, low education, socioeconomic income <UMP, low knowledge level, cleanliness level is bad, contact history level $>2$ years and compliance level Drinking good medicine. The result of bivariate anahsis showed significant relationship between Work $(P=0,06)$, education $(P=0,06)$, socioeconomic $(P=0,032)$, knowledge $(P=0,027)$, cleanliness $(p=0,012)$, and contact history $(p=0,003)$ against the incidence of leprosy. The research concludes the work, education, social economy, knowledge, cleanliness and contact history affect the incidence of leprosy while age, Gender and medication adherence did not affect the incidence of leprosy in the Work Area of Bakunase Community Health Center.
\end{abstract}

Keywords: Leprosy, Factors Affecting Leprosy, Bakunase.

\footnotetext{
* Correspondence: mutansir@staf.undana.ac.id

Present Address: Adisucipto St., Lasiana, Kupang, East Nusa tenggara - Indonesia. 85000

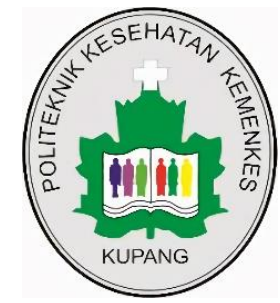

CThe Author(s) 2018. This article is distributed under the terms of the Creative Commons Attribution 4.0 International License (http://creativecommons.org/licenses/by/4.0/), which permits unrestricted use, distribution, and reproduction in any medium, provided you give appropriate credit to the original author(s) and the source, provide a link to the Creative Commons license, and indicate if changes were made. The Creative Commons Public Domain Dedication waiver (http://creativecommons.org/publicdomain/zero/1.0/) applies to the data made available in this article, unless otherwise stated.
} 


\section{PENDAHULUAN}

Penyakit kusta disebut juga sebagai penyakit Lepra atau penyakit Morbus Hansen disebabkan oleh bakteri Mycobacterium leprae. Bakteri ini mengalami proses pembelahan cukup lama antara 2-3 minggu. Daya tahan hidup kuman kusta mencapai 9 hari di luar tubuh manusia. Kuman kusta memiliki masa inkubasi 2-5 tahun bahkan juga dapat memakan waktu lebih dari 5 tahun (Kemenkes RI, 2015).

Jumlah penderita kusta yang dilaporkan dari 121 negara di 5 regional WHO sebanyak 175.554 kasus di akhir tahun 2014 dengan 213.899 kasus baru (www.who.int). Penatalaksanaan kasus kusta yang buruk dapat menyebabkan kusta menjadi progresif, menyebabkan kerusakan permanen pada kulit, saraf, anggota gerak, dan mata. Indonesia berada pada peringkat ketiga negara penyumbang kusta terbesar di dunia setelah India dan Brasil. Setiap tahun selalu ditemukan kasus baru dalam jumlah yang besar.

Berdasarkan klasifikasi WHO dan Modifikasi WHO mengelompokkan tipe keparahan: Pausibasiler (PB) Penyakit ini mengandung banyak basil dan terdiri atas tipe Indeterminate, Tuberkuloid, Borderline Tuberkuloid. Jumlah lesi sebanyak 1 hingga 5 lesi kulit. Hasil pemeriksaan basil tahan asam BTA negatif. Multibasiler (MB) Penyakit ini mengandung sedikit basil dan terdiri atas tipe Borderline, Borderline Lepromatous, Lepromatous. Jumlah lesi lebih atau sama dengan 6 lesi kulit. Hasil pemeriksaan BTA positif (Amirudin, 2012).

Jumlah kasus kusta di seluruh dunia selama 12 tahun terakhir ini telah menurun tajam di sebagian besar negara atau Wilayah endemis. Kasus yang terdaftar pada permulaan tahun 2009 tercatat 213.036 penderita yang berasal dari 121 negara, sedangkan jumlah kasus baru tahun 2008 baru tercatat 249.007 Jumlah kasus baru kusta di dunia pada awal tahun 2013 adalah sebesar 232.287. Dari jumlah tersebut paling banyak terdapat di regional Asia Tenggara (166.445), diikuti regional Amerika (36.178), regional Afrika (20.599), dan sisanya berada di regional lain di dunia (WHO, 2013 dalam Kemenkes 2014).

Data Kementerian Kesehatan RI (2016) menyebutkan angka CDR di Indonesia sebesar tahun 2015 yaitu 6,73 kasus baru per 100.000 penduduk, menurun dibanding tahun 2011 sebesar 8,03 per 100.000 penduduk. Meskipun demikian data tersebut tergolong endemik rendah dan berpotensi menjadi sumber penularan bagi masyarakat. Status eliminasi kejadian kusta di Indonesia dibagi menjadi 2 kelompok yaitu provinsi yang belum eliminasi dan provinsi yang sudah mencapai eliminasi. Provinsi yang belum mencapai eliminasi jika angka prevalensi $>1$ per 10.000 
penduduk, sedangkan provinsi yang sudah mencapai eliminasi jika angka prevalensi < 1 per 10.000 penduduk (Kemenkes RI, 2016).

Data dari 34 provinsi, sebanyak 12 provinsi (35,3\%) termasuk dalam provinsi yang belum eliminasi. Sedangkan 22 provinsi lainnya $(64,7 \%)$ termasuk dalam provinsi yang sudah eliminasi. Berdasarkan data tersebut dapat di ketahui bahwa provinsi NTT termaksud dalam dalam 22 provinsi yang sudah tereliminasi.

Pembangunan Kesehatan di Provinsi Nusa Tenggara Timur (NTT) diarahkan untuk meningkatkan kesadaran, kemauan dan kemampuan hidup sehat bagi setiap orang agar terwujud derajat kesehatan masyarakat yang optimal sehingga dapat hidup produktif secara sosial dan ekonomi.

Pada tahun tahun 2011-2015 dilaporkan bahwa kasus Kusta di NTT mengalami fluktuasi, pada tahun 2011 sebesar 343 kasus dan pada tahun 2012 mengalami peningkatan menjadi 486 kasus selanjutnya pada tahun 2013 menurun menjadi 430 kasus, pada tahun 2014 meningkat lagi menjadi 575 kasus, dan pada tahun 2015 menjadi 306 kasus (CDR 5,98 per 100.000 penduduk), berarti terjadi penurunan kasus. Jika dikaitkan dengan indikator yang ada pada Renstra Dinkes Provinsi NTT berarti NCDR Provinsi NTT pada tahun 2015 masuk kriteria low endemic ( $>10$ per 100.000 penduduk). (Profil kesehatan NTT, 2015)
Jumlah kusta tertingi berdasarkan kabupaten di provinsi NTT terdapat pada kabupaten Flores Timur dengan persentase $72 \%$, kemudian di ikuti oleh Kota Kupang 64\%. Sedangkan kabupaten yang tidak memiliki kasus yaitu kabupaten Kupang, Nagekeo, Mangarai Timur, Mangarai, Mangarai Barat, dan Sumba Barat 0\%(profil: kesehatan NTT, 2015)

Undang-Undang Nomor 36 Tahun 2009 Tentang Kesehatan secara gamblang mengamanatkan bahwa setiap orang berhak atas informasi dan edukasi tentang kesehatan yang seimbang dan bertanggung jawab, serta visi kontak kupang yang menyatakan "Mewujudkan Masyarakat yang Sehat dan Produktif melalui Pelayanan Kesehatan yang Modern dan Profesional”

Puskesmas Bakunase merupakan salah satu puskesmas satelit yang berada pada Wilayah Kota Kupang. Puskesmas Bakunase memperoleh kejadian kusta yang yang semakin meningkat tiap tahunnya, di mana pada tahun 2012 berjumlah 10 orang, tahun 2013 berjumlah 12 orang, tahun 2014 berjumlah 19 orang, tahun 2015 berjumlah 2016 berjumlah 14 orang, tahun 2016 berjumlah 23 dan kasus baru tahun 2017 bulan januari-agustus 13 orang. Berdasarkan kasus yang di peroleh dalam kurun waktu 5 tahun terahir peningkatan kasus yang tinggi terjadi pada tahun 2016. (Profil Puskesmas Bakunase, 2016). 
Faktor yang berhubungan dengan kejadian kusta juga dapat diketahui dari berbagai hasil penelitian berikut; (Agustina Lasari dkk, 2013) menunjukkan bahwa terdapat hubungan yang bermakna antara pengetahuan dan sikap keluarga dengan tingkat kecacatan penderita kusta di kabupaten Padang Pariaman, (Andy muharry, 2014) Kondisi ekonomi keluarga yang rendah dan kebersihan perorangan yang buruk dapat mempengaruhi kejadian kusta, (Riyanto martomijoyo, 2014) menunjukkan hubungan antara tingkat pendidikan dengan kejadian penyakit kusta di Kecamatan Tukdana Kabupaten Indramayu, (Lia Setiani, 2014) menyatakan bahwa ada hubungan antara kepadatan hunian dengan penyakit kusta, adanya hubungan antara lama kontak dengan penyakit kusta dan ada hubungan antara kebersihan individu dengan kejadian kusta, (Smet, 1994) Kepatuhan yaitu tingkat/derajat di mana penderita suatu penyakit dalam hal ini penyakit kusta mampu melaksanakan cara pengobatan dan perilaku yang disarankan oleh dokter atau tim kesehatan lainnya, dan merupakan tingkat di mana perilaku seseorang sesuai dengan saran praktisi kesehatan dan (Depkes RI, 2006) Penderita yang sudah dalam keadaan cacat permanen, pengobatan hanya dapat mencegah cacat lebih lanjut. Bila penderita tidak minum obat secara teratur, maka kuman kusta dapat menjadi aktif kembali, sehingga timbul gejala-gejala baru pada kulit dan saraf yang dapat memperburuk keadaan.

Kejadian kusta juga dapat dijelaskan berdasarkan teori yang mempunyai hubungan, seperti yang diungkapkan pada teori; a) Teori Lawrence Green tentang determinan Perilaku Kesehatan menyatakan faktor yang memengaruhi kesehatan yakni: Faktor-faktor Predisposisi (disposing faktors), Faktor-faktor Pemungkin (enabling faktors), Faktor-faktor Penguat (reinforcing faktors) b) Teori Hendrik L Blum menyatakan faktor yang mempengaruhi yaitu; faktor perilaku, faktor lingkungan, faktor pelayanan kesehatan dan faktor genetika. c) Teori Gorden pada segi tiga epidemologi juga mengambarkan dengan jelas berbagai hubungan yang mempengaruhi masalah kesehatan di mana tidak adanya keseimbangan antara host agen dan environment. d) serta status sosial ekonomi seperti yang disampaikan oleh FS. Chapin (Karne, 1989) status sosial ekonomi merupakan tinggi rendahnya persentase yang dimiliki seseorang berdasarkan kedudukkanya di masyarakat yang didasarkan pada pekerjaan untuk memenuhi kebutuhannya berdasarkan kepemilikan materi dan sosial ekonomi juga merupakan segala kegiatan yang bisa menghasilkan uang dan juga termasuk cakupan rumah tangga (Depdiknas, 
2002). Tingkat ekonomi seseorang dapat mempengaruhi derajat kesehatannya. Hal ini terbukti bahwa penderita kusta yang status ekonominya lebih tinggi sulit bersosialisasi dengan masyarakat karena mereka merasa malu. Sedangkan penderita yang status ekonominya rendah lebih mudah bersosialisasi dengan masyarakat karena dipengaruhi oleh faktor pekerjaanya dan tuntutan ekonomi (Depkes RI, 2007).

Berdasarkan latar belakang kejadian kusta di atas maka penulis tertarik untuk melakukan kajian penelitian dengan judul "Studi FaktorFaktor Yang Berhubungan Dengan Kejadian Penyakit Kusta Pada Wilayah Kerja Puskesmas Bakunase Kota Kupang Tahun 2017"

\section{METODOLOGI PENELITIAN}

Penelitian ini dilakukan pada bulan Novenber 2017- Januari 2018. Jenis penelitian ini adalah penelitian survey analitik dengan rancangan penelitian cross sectional. Jumlah responden dalam penelitian ini adalah 33 orang tehnik yang digunakan nonprobability sampling dengan mengunakan total sampling (Siswanto, 2013)

Variabel bebas dalam penelitian ini yaitu karakteristik (umur, jenis kelamin, pendidikan, pengetahuan, pekerjaan dan reaksi obat), Perilaku kebersihan, sosial ekonomi, riwayat kontak dan ketaatan berobat penderita Kusta di Puskesmas Bakunase. (Sugiyono, 2009).

\section{HASIL DAN PEMBAHASAN PENELITIAN}

\section{Umur}

Umur adalah variabel yang selalu diperlihatkan di dalam penyelidikanpenyelidikan epidemiologi. Kebanyakan penelitian melaporkan distribusi penyakit kusta menurut umur berdasarkan prevalensi, hanya sedikit yang berdasarkan insiden karena pada saat timbulnya penyakit sangat sulit diketahui. Dengan kata lain kejadian penyakit sering terkait pada umur pada saat diketemukan dari pada saat timbulnya penyakit

Hasil penelitian terhadap umur pada Wilayah Kerja Puskesmas Bakunase Tahun 2017 dapat diketahui bahwa responden paling banyak berada pada usia $<15$ dan $>29$ tahun yaitu 25 orang $(75,8 \%)$ diantaraannya 13 sakit dan 12 sembuh. Sedangkan responden yang berada pada umur 15-29 tahun yaitu 8 orang $(24,2 \%)$ diantaranya 5 sakit dan 3 sembuh.

Hasil uji statistik menunjukkan bahwa variabel Umur merupakan faktor yang berpengaruh terhadap kejadian kusta karena memiliki nilai $\mathrm{OR}>1$ yakni sebesar 1,53 dan pada Confidence Interval mencakup angka 1 (0,301$7,870)$. Namun variabel ini tidak memiliki pengaruh yang signifikan terhadap Kejadian kusta di Wilayah Kerja 
Puskesmas Bakunase Kota Kupang tahun 2017, karena memiliki nilai $\mathrm{p}$ value $=$ $0,604(p>0,05)$.

Pada usia produktif manusia berperan aktif dalam berhubungan dengan dunia luar, baik pekerjaan maupun berhubungan dengan lingkungan sekitar apabila dibandingkan dengan usia balita atau lansia, sehingga pada usia produktif inilah manusia menjadi lebih rentan terjangkit berbagai penyakit (Depkes RI, 1999).

Penelitian ini sejalan dengan penelitian yang dilakukan Dewi Sendy Ramadhani dkk, tentang determinan kejadian penyakit kusta di wilayah kerja puskesmas kecamatan Limo Tahun 2013, dimana hasil uji statistic menunjukkan bahwa nilai $\mathrm{P}$ Value $=0,747$ berarti $\mathrm{P}$ Value $>0,05$, sehingga dapat disimpulkan bahwa tidak terdapat pengaruh yang signifikan antara Umur terhadap Kejadian Penyakit Kusta di Wilayah Kerja Puskesmas Kecamatan Limo, Kota Depok, Jawa Barat.

\section{Jenis kelamin}

Penyakit kusta menyerang semua orang. Laki-laki lebih banyak terkena dibandingkan dengan wanita, dengan perbandingan 2:1. Walaupun ada beberapa daerah yang menunjukkan insidens ini hampir sama bahkan ada daerah yang menunjukkan penderita wanita lebih banyak. Kusta dapat mengenai laki-laki dan perempuan. Menurut catatan sebagian besar Negara di dunia kecuali di berberapa Negara di Afrika menunjukkan bahwa laki-laki lebih banyak terserang dari pada wanita relative (Marwali Harahap, 2000).

Hasil penelitian terhadap jenis kelamin pada Wilayah Kerja Puskesmas Bakunase tahun 2017, dapat diketahui bahwa responden paling banyak laki-laki yaitu 31 orang $(93,9 \%)$ diantaraannya 17 sakit dan 14 sembuh. Sedangkan responden Wanita yaitu 2 orang $(60,1 \%)$ diantaranya 1 sakit dan 1 sembuh.

Hasil uji statistik menunjukkan bahwa variabel jenis kelamin bukan merupakan faktor yang berpengaruh terhadap kejadian kusta karena memiliki nilai $\mathrm{OR}<1$ yakni sebesar 0,84 dan pada Confidence Interval mencakup angka 1 $(0,301-7,870)$ variabel ini juga tidak memiliki pengaruh yang signifikan terhadap Kejadian kusta di Wilayah Kerja Puskesmas Bakunase Kota Kupang tahun 2017 karena memiliki nilai $\mathrm{p}$ value $=$ $0,894(p>0,05)$.

Hasil penelitian ini sesuai dengan pendapat dari Marwali Harahap (200) yang menyatakan bahwa penyakit kusta dapat menyerang semua orang. Laki-laki lebih banyak terkena dibandingkan dengan wanita, dengan perbandingan $2: 1$. Walaupun ada beberapa daerah yang menunjukkan insidens ini hampir sama 
bahkan ada daerah yang menunjukkan penderita wanita lebih banyak. Begitu juga seperti yang ada dalam Depkes RI, (2007) bahwa laki-laki lebih banyak terserang dari pada wanita. Relatif rendahnya kejadian kusta pada perempuan kemungkinan karena faktor lingkungan atau faktor biologi. Seperti kebanyakan penyakit menular lainnya laki-laki lebih banyak terpapar dengan faktor risiko sebagai akibat gaya hidupnya

\section{Pendidikan}

Pendidikan adalah usaha sadar dan terencana untuk mewujudkan suasana belajar dan proses pembelajaran agar peserta didik secara aktif mengembangkan potensi dirinya untuk memiliki semangat spiritual keagamaan, pengendalian diri, kepribadian, kecerdas- an akhlak mulia keterampilan yang diperlukan dirinya, masyarakat, bangsa dan negara.

Rendahnya tingkat pendidikan dapat mengakibatkan lambatnya pencarian pengobatan dan diagnosis penyakit, hal ini dapat mengakibatkan kecacatan pada penderita kusta semakin parah.

Hasil penelitian tingkat pendidikan pada Wilayah Kerja Puskesmas Bakunase terhadap kejadian kustas Tahun 2017, dapat diketahui bahwa responden paling banyak berada pada tingkat pendidikan rendah yaitu 22 orang (66,7\%) diantaraannya 15 sakit dan 7 sembuh. Sedangkan responden yang berada pada tingkat pendidikan yaitu 11 orang (33,3\%) diantaranya 3 sakit dan 8 sembuh.

Hasil uji statistik menunjukkan bahwa variabel pendidikan merupakan faktor yang berpengaruh terhadap kejadian kusta karena memiliki nilai OR>1 yakni sebesar 5,65 dan pada Confidence Interval mencakup angka 1 (0,43-72.821) variabel ini juga memiliki pengaruh yang signifikan terhadap Kejadian kusta di Wilayah Kerja Puskesmas Bakunase Kota Kupang tahun 2017 karena memiliki nilai $\mathrm{p}$ value $=$ $0,026(p<0,05)$.

Hasil penelitian ini yaitu penderita kusta lebih banyak yang memiliki tingkat pendidikan rendah. Pendidikan yang rendah oleh penderita sebagai salah satu faktor yang berhubungan dengan kejadian kusta karena seperti yang diungkapkan oleh Soekidjo Notoatmodjo (2005) dan Budioro (1997) bahwa tingkat pendidikan dianggap sebagai salah satu unsur yang menentukan pengalaman dan pengetahuan seseorang, baik dalam ilmu pengetahuan maupun kehidupan sosial.

Penelitian ini sejalan dengan penelitian yang dilakukan oleh Riyanto Martomijoyo tentang faktor-faktor yang memengaruhi kejadian penyakit kusta pada penduduk di kecamatan Tukdana kabupaten Indramayu tahun 2012. Hasil uji statistik menunjukkan nilai $\rho$ value $=$ 
0,03 pada $\alpha=0,05$. Karena nilai $\rho$ value < 0,05 , berarti menunjukkan bahwa ada hubungan antara tingkat pendidikan responden dengan kejadian kusta di kecamatan Tukdana.

\section{Pengetahuan}

Pengetahuan adalah hasil penginderaan manusia atau hasil tahu seseorang terhadap objek melalui indera yang dimilikinya (mata, hidung, telinga dan sebagainya). Secara sendirinya, pada waktu penginderaan sampai menghasilkan pengetahuan tersebut sangat dipengaruhi oleh intensitas perhatian dan persepsi terhadap objek yang berbeda-beda (Soekidjo Notoatmodjo, 2005). Pengetahuan yang baik diharapkan menghasilkan kemampuan seseorang dalam mengetahui gejala, cara penularan penyakit kusta dan penanganannya.

Hasil penelitian Tigkat Pengetahuan Kusta ada Wilayah Kerja Puskesmas Bakunase terhadap kejadian kusta Tahun 2017, dapat diketahui bahwa responden paling banyak menyatakan Tidak tahu yaitu 20 orang (60,6\%) diantaraanya 14 sakit dan 76 sembuh. Sedangkan responden yang menyatakan tahu yaitu 13 orang $(39,4 \%)$ diantaranya 4 sakit dan 9 sembuh.

Hasil uji statistik menunjukkan bahwa variabel Pengetahuan merupakan faktor yang berpengaruh terhadap kejadian kusta karena memiliki nilai OR>1 yakni sebesar 18,16 dan pada Confidence Interval mencakup angka 1 (1,139-289.532) variabel ini juga memiliki pengaruh yang signifikan terhadap Kejadian kusta di Wilayah Kerja Puskesmas Bakunase Kota Kupang tahun 2017 karena memiliki nilai $\mathrm{p}$ value $=$ $0,027(\mathrm{p}<0,05)$.

Menurut Notoatmodjo (2003) pengetahuan adalah hasil dari tahu, dan ini terjadi setelah orang melakukan penginderaan terhadap suatu obyek tertentu. Penginderaan terjadi melalui panca indera manusia, yakni indera penglihatan, pendengaran, penciuman, rasa, dan raba. Sebagian besar pengetahuan manusia diperoleh melalui mata dan telinga. Pengetahuan juga di pengaruhi oleh beberapa faktor yaitu faktor internal (umur dan perilaku), dan faktor eksternal (pendidikan, lingkungan, dan informasi). Pada umumnya semakin tinggi pendidikan seseorang maka akan semakin baik pula tingkat, dengan memberikan informasiinformasi tentang cara-cara mencapai hidup sehat, cara pemeliharaan kesehatan, cara menghindari penyakit dan sebagainya akan meningkatkan pengetahuan masyarakat tentang hal tersebut (Notoatmodjo, 2003)

Memperhatikan teori determinan perilaku kesehatan dari Lawrence Green dalam Notoatmodjo (2003) yang 
menyatakan bahwa perilaku dipengaruhi oleh faktor predisposisi, salah satunya adalah pengetahuan. Pengetahuan yang diperoleh oleh individu dapat membangun sikap dan persepsi sebagai dasar untuk bertindak. Hasil penelitian ini sesuai dengan teori Green menyatakan bahwa adanya kecenderungan seseorang yang berpengetahuan tinggi akan lebih cenderung untuk berperilaku baik dalam bidang kesehatan dalam hal ini mencegah kecacatan keluarganya yang menderita penyakit kusta.

Penelitian ini sejalan dengan penelitian Anas Tamsuri (2008), tentang hubungan pengetahuan dan perilaku pencegahan penularan penyakit kusta di wilayah kerja puskesmas tanjunganom kabupaten Nganjuk. Hasil uji statistik didapatkan hubungan antara pengetahuan dan perilaku pasien dalam upaya pencegahan penularan penyakit kusta adalah signifikan $(\mathrm{p}=0,000)$ dengan koefisien korelasi 0,616 (cukup kuat).

\section{Pekerjaan}

Pekerjaan adalah aktivitas utama yang dilakukan oleh manusia. Dalam arti sempit, istilah pekerjaan digunakan untuk suatu tugas atau Kerja yang menghasilkan uang bagi seseorang. Dalam pembicaraan sehari-hari istilah ini sering dianggap sinonim dengan profesi.
Sebagian besar penderita kusta di dunia berada di negara yang sedang berkembang termasuk Indonesia, sebagaian besar penduduk Indonesia mencari penghasilan dengan bercocok tanam atau bertani. Hal ini sangat berpengaruh terhadap terjadinya cacat pada kusta. Penelitian yang dilakukan di Nepal oleh Ghimire (1996),

Hasil penelitian Pekerjaan dapat diketahui bahwa responden paling banyak berada pada pekerjaan yang berisiko yaitu 22 orang (66,7\%) diantaraannya 9 sakit dan 13 sembuh. Sedangkan responden yang berada pada pekerjaan tidak berisiko yaitu 11 orang (33,3\%) diantaranya 9 sakit dan 2 sembuh.

Penelitian ini tidak sejalan dengan penelitian Yessita Yuniarasari tentang faktor risiko yang berhubungan dengan kejadian kusta di Wilayah Kerja Puskesmas Gunem dan Sarang Kabupatem Rembang tahun 2011. Hasil uji statistik menunjukkan bahwa variabel pekerjaan bukan merupakan faktor yang berpengaruh terhadap kejadian kusta karena memiliki nilai OR $<1$ yakni sebesar 0,50 dan pada Confidence Interval mencakup angka 1 (0,0001-312.020). Namun variabel ini memiliki pengaruh yang signifikan terhadap Kejadian kusta di Wilayah Kerja Puskesmas Bakunase Kota Kupang tahun 2017 karena memiliki nilai $p$ value $=0,026(p<0,05)$. 
Penelitian ini sejalan dengan penelitian Yessita Yuniarasari pada Wilayah Kerja puskesmas Gunem dan puskesmas Sarang Kabupaten Rembang tahun 2011. Hasil ini didasarkan pada uji Chi-square, diperoleh nilai $\mathrm{p}(0,001)<\alpha$ $(0,05)$. N ilai odd ratio sebesar 11,400 dan 95\% CI (3,092-42,026) sehingga dapat diketahui bahwa responden yang memiliki pekerjaan berat berisiko 11,400 kali lebih besar terkena kusta daripada responden yang memiliki pekerjaan ringan. $\mathrm{N}$ ilai OR > 1 dan 95\% CI tidak mencakup angka1, berarti pekerjaan merupakan salah satu faktor risiko kejadian kusta.

\section{Perekonomian}

WHO (2003) menyatakan 90\% penderita kusta di dunia menyerang kelompok dengan sosial ekonomi lemah atau miskin. Hubungan antara kemiskinan dengan penyakit kusta bersifat timbal balik. Kusta merupakan penyebab kemiskinan dan karena miskin maka manusia menderita kusta. Kondisi sosial ekonomi itu sendiri, mungkin tidak hanya berhubungan secara langsung, namun dapat merupakan penyebab tidak langsung seperti adanya kondisi gizi memburuk, serta perumahan yang tidak sehat, hygiene sanitasi yang kurang dan akses terhadap pelayanan kesehatan juga menurun kemampuannya.
Hasil penelitian Tingkat Perekonomian pada Wilayah Kerja Puskesmas Bakunase terhadap kejadian kusta Tahun 2017, dapat diketahui bahwa responden paling banyak berada pada tingkat perekonomian <UMP yaitu 25 orang $(75,8 \%)$ diantaraannya 11 sakit dan 14 sembuh. Sedangkan responden yang berada pada tingkat perekonomian >UMP yaitu 8 orang $(24,2 \%)$ diantaranya 7 sakit dan 1 sembuh.

Hasil uji statistik menunjukkan bahwa variabel pendidikan bukan merupakan faktor yang berpengaruh terhadap kejadian kusta karena memiliki nilai $\mathrm{OR}<1$ yakni sebesar 0,37 dan pada Confidence Interval mencakup angka 1 (0,00-297.329) variabel ini juga memiliki pengaruh yang signifikan terhadap Kejadian kusta di Wilayah Kerja Puskesmas Bakunase Kota Kupang tahun 2017 karena memiliki nilai $\mathrm{p}$ value = $0,032(\mathrm{p}<0,05)$.

Sudah diketahui bahwa faktor sosial ekonomi sangat berperan penting dalam kejadian kusta. Hal ini terbukti pada negara-negara di Eropa dengan adanya peningkatan sosial ekonomi, maka kejadian kusta akan cepat menurun bahkan hilang. Kasus kusta impor pada negara tersebut ternyata tidak menularkan pada orang yang tingkat sosial ekonominya tinggi. Kegagalan kasus kusta impor untuk menularkan pada kasus kedua di Eropa juga 
disebabkan karena tingkat sosial kebun pada masyarakat pragaan ekonomi yang tinggi (Depkes RI, 2006). menyebabkan penularan penyakit kusta.

Penelitian ini sejalan dengan penelitian silvia Indriani (2014) tentang faktor risiko yang berhubungandengan kejadian kusta (Studi Kasus Di Wilayah Kerja Puskesmas Kunduran Blora. Hasil penelitian menunjukkan bahwa ada hubungan antara status sosial ekonomi dengan kejadian kustadi wilayah kerja puskesmas Kunduran, Blora. Hasil ini didasarkan pada uji Chi-square, diperoleh nilai $p(0,000)<\alpha(0,05)$. Nilai odd ratio sebesar 6,296 dan 95\% CI $(2,380-20,157)$ sehingga dapat diketahui bahwa responden yang memiliki status sosial ekonomi rendah memiliki risiko 6,296 kali lebih besar mengalami kejadian kusta dibandingkan responden yang memiliki status sosial ekonomi tinggi.

\section{Kebersihan}

Personal hygiene adalah tindakan pencegahan yang menyangkut tangung jawab individu untuk meningkatkan kesehatan serta membatasi peyebarnya penyakit menular, terutama yang ditularkan secara kontak langsung (Nur Nasry Noor, 2006)

Menurut hasil penelitian Yudied A.M tahun (2008) bawah personal hygiene meliputi kebiasan tidur bersama ,pakai pakayan bergantian ,handuk mandi secara bergantian serta $B A B$ di

Hasil uji statistik menunjukkan bahwa variabel pendidikan bukan merupakan faktor yang berpengaruh terhadap kejadian kusta karena memiliki nilai OR $<1$ yakni sebesar 0,27 dan pada Confidence Interval mencakup angka 1 (0,014-5.363) variabel ini juga memiliki pengaruh yang signifikan terhadap Kejadian kusta di Wilayah Kerja Puskesmas Bakunase Kota Kupang tahun 2017 karena memiliki nilai $\mathrm{p}$ value $=$ $0,012(p<0,05)$.

Penelitian ini sejalan dengan penelitian yang dilakukan oleh Andy Muharri tentang faktor-faktor apakah yang berpengaruh terhadap kejadian kusta di Kecamatan Tirto Kabupaten Pekalongan 2007. Hasil uju statistic menunjukkan nilai p sebesar 0,000 yang artinya ada hubungan yang bermakna antara kebersihan perorangan dengan kejadian kusta. Nilai Odds Ratio didapatkan OR =12,103 (95\% CI=3,855- 
38,000 ) berarti seseorang yang memiliki kondisi kebersihan perorangan buruk mempunyai risiko 12,103 kali lebih besar menderita kusta dibandingkan dengan seseorang yang memiliki kondisi kebersihan perorangan baik.

Menurut teori yang dikemukakan oleh Linda Tietjen (2004) cuci tangan adalah proses membuang kotoran dan debu secara mekanis dari kulit kedua belah tangan dengan memakai sabun dan air. Kesehatan dan kebersihan dapat mengurangi jumlah mikroorganisme penyebab penyakit pada kedua tangan dan lengan serta meminimalisasi kontaminasi silang. Menurut Blum faktor yang mempengaruhi status kesehatan adalah lingkungan, perilaku, keturunan, dan pelayanan kesehatan. Perilaku sehat adalah semua perilaku kesehatan yang dilakukan atas dasar kesadaran yang mana perilaku atau kegiatan tersebut berkaitan dengan upaya mempertahankan dan meningkatkan kesehatan, serta mencangkup perilaku dalam pencegahan menghindari dari berbagai macam penyakit, penyebab penyakit atau masalah kesehatan untuk meningkatkan status kesehatan (Notoatmodjo, 2010).

\section{Riwayat kontak}

Kusta merupakan penyakit infeksius, tetapi derajat infektifitasnya rendah, waktu inkubasinya panjang, mungkin beberapa tahun dan tampakanya kebanyakan pasien mendapatkan infeksi sewaktu semasa anak-anak. Insiden yang rendah pada pasien-pasien yang merupakan pasangan suami istri (kusta yang diperoleh dari pasangan) memberikan kesan bahwa orang dewesa relative tidak mudah terkena. Penyakit ini terkena akibat kontak fisik yang erat dengan pasien yang terinfeksi, dan resiko ini semakin menjadi menjadi lebih besar bila terjadi kontak dengan penderita lepramatosa. Secret hidung merupakan sumber utama terjadi infeksi dimasyarakat (Robin graham brown, 2005)

Hasil penelitian yang diperoleh pada Wilayah Kerja Puskesmas Bakunase terhadap kejadian kusta Tahun 2017, bahwa riwayat kontak merupakan faktor risiko kejadian penyakit kusta sekaligus berhubungan dengan kejadian penyakit kusta. Hasil uji statistik diperoleh nilai OR yaitu 24.913 lebih besar dari 1, hal ini menunjukkan bahwa riwayat kontak merupakan faktor risiko kejadian penyakit kusta atau orang dengan riwayat kontak berisiko 24.913 kali lebih besar terinfeksi penyakit kusta dibandingkan dengan tidak ada riwayat kontak. Nilai lower limit dari uji statistik yaitu 2.383 dan upper limit yaitu 260.474 dimana tidak mencakup nilai 1 , hal ini menunjukkan bahwa riwayat kontak merupakan faktor risiko yang bermakna 
secara signifikan terhadap kejadian penyakit kusta.

Pada penelitian ini diperoleh data bahwa dari 33 responden yang mempunyai riwayat kontak $>2$ tahun, terdapat 20 responden (60,6 \%) diantaranya 14 mengalami sakit dan 6 telah dinyatakan sembuh. Sedangkan yang mempunyai riwayat kontak < 2 tahun terdapat 13 responden $(39,4 \%)$ diantaranya 3 mengalami sakit dan 10 telah dinyatakan sembuh.

Meskipun belum diketahui secara pasti tentang bagaimana cara penularan penyakit kusta, namun secara teoritis penularan ini dapat terjadi secara kontak yang lama dengan penderita baik serumah maupun tidak serumah (Depkes RI, 2006).

Secara teoritis penularan ini dapat terjadi dengan kontak yang erat dan lama dengan penderita, namun penderita dengan kusta tipe basah atau multi basiler, tetapi penularan ini juga dipengaruhi oleh daya tahan tubuh seseorang. Meskipun lama kontak kurang dari dua tahun, tetapi jika seseorang memiliki riwayat kontak yang tinggi dengan penderita kusta yang belum diobati, maka akan menyebabkan penularan penyakit kusta yang relatif singkat, karena penyakit kusta yang tidak minum obat sesuai dengan regimen WHO, merupakan sumber penularan bagi orang lain.
Penelitian ini sejalan dengan penelitian Tasalina Yohana Parameswari Gustam dkk, tentang hubungan antara riwayat kontak dengan kejadian kusta multibasiler di kecamatan Kenjeran, Kecamatan Semampir dan Kecamatan Tandes Surabaya tahun 2017, Hasil penelitian menunjukkan: $P$ value $0.003<$ 0.05 menunjukkan bahwa ada hubungan antara riwayat kontak dengan kejadian kusta dengan nilai OR 5.278 (CI 95\%:1.687-16.514). Simpulan: Terdapat hubungan antara riwayat kontak dengan kejadian kusta di Kecamatan Kenjeran, Tandes dan Semampir. Responden yang memiliki riwayat kontak dengan penderita kusta berisiko 5.278 kali terkena kusta dibandingkan responden yang tidak memiliki riwayat kontak.

\section{Kepatuhan minum obat}

Tujuan pengobatan penderita kusta adalah untuk memutuskan mata rantai penularan, menyembuhkan penyakit penderita dan mencegah terjadinya kecacatan atau bertambah cacat. Pengobatan penderita kusta ditujukan untuk mematikan kuman kusta sehingga tidak berdaya merusak jaringan tubuh dan tanda-tanda penyakit jadi kurang aktif sampai akhirnya hilang (Depkes RI, 2015).

Penderita yang sudah dalam keadaan cacat permanen, pengobatan hanya dapat mencegah cacat lebih lanjut. Bila penderita tidak minum obat secara teratur, maka kuman kusta dapat 
menjadi aktif kembali, sehingga timbul gejala-gejala baru pada kulit dan saraf yang dapat memperburuk keadaan (Depkes RI, 2006).

Hasil penelitian Kepatuhan Minum obat pada Wilayah Kerja Puskesmas Bakunase terhadap kejadian kusta tahun 2017, dapat diketahui bahwa responden paling banyak berada pada kondisi patuh yaitu 27 orang $(81,8 \%)$ diantaraannya 14 sakit dan 13 sembuh. Sedangkan responden yang berada pada tingkat kebersihan yang baik yaitu 6 orang $(18,2$ \%) diantaranya 4 sakit dan 2 sembuh.

Hasil uji statistik menunjukkan bahwa variabel pendidikan merupakan faktor yang berpengaruh terhadap kejadian kusta karena memiliki nilai OR>1 yakni sebesar 0,27 dan pada Confidence Interval mencakup angka 1 (0,014-5.363). Namun variabel ini tidak memiliki pengaruh yang signifikan terhadap Kejadian kusta di Wilayah Kerja Puskesmas Bakunase Kota Kupang tahun 2017 karena memiliki nilai $\mathrm{p}$ value $=$ $0,510(\mathrm{p}<0,05)$.

Penelitian ini sejalan Putrid Catrina dkk, tentang faktor-faktor yang berhubungan dengan tingkat kecacatan klien kusta 2015. Hasil analisis lebih lanjut menunjukkan nilai $\rho(0,520)>\alpha$ $(0,05)$ hal ini menunjukkan bahwa tidak terdapat hubungan antara pengobatan dengan tingkat kecacatan klien kusta di
Kelurahan Bitahan RT 11 dan 12 wilayah kerja puskesmas Lokpaikat.

Penelitian ini tidak sejalan dengan penelitian Wiyarni dkk, tentang hubungan kepatuhan minum obat kusta dan dukungan keluarga Dengan kecacatan pada penderitakusta di Kabupaten Kudus Hasil penelitian diperoleh sebagian besar penderita kusta tidak patuh dalam minum obat yaitu sebanyak 48 orang (62,3\%), dengan Nilai $\mathrm{p}$ value adalah 0,003 $(<0,05)$. Dapat disimpulkan ada hubungan kepatuhan minum obat kusta dengan kecacatan pada penderita kusta di Kabupaten Kudus, tahun 2013 ( $\mathrm{p}$ value 0,004<0,05).

\section{KESIMPULAN}

\section{Simpulan}

1. Adanya hubungan antara pendidikan, pengetahuan dan pekerjaan. Sedangkan umur dan jenis kelamin tidak berhubungan dengan kejadian kusta pada Wilayah Kerja Puskesmas Bakunase kecamatan Kota Raja Kota Kupang.

2. Adanya hubungan antara perekonomian dengan kejadian kusta pada Wilayah Kerja Puskesmas Bakunase kecamatan Kota Raja Kota Kupang.

3. Adanya hubungan antara kebersihan dengan kejadian kusta pada Wilayah Kerja Puskesmas Bakunase kecamatan Kota Raja Kota Kupang. 
4. Adanya hubungan antara riwayat kontak dengan kejadian kusta pada Wilayah Kerja Puskesmas Bakunase kecamatan Kota Raja Kota Kupang.

5. Tidak adanya hubungan antara kepatuhan Minum Obat dengan kejadian kusta pada Wilayah Kerja Puskesmas Bakunase Kecamatan Kota Raja Kota Kupang.

\section{SARAN}

1. Bagi peneliti selanjutnya

Dapat dijadikan bahan referensi bagi peneliti lain yang akan mengembangkan penelitian selanjutnya dan dapat dijadikan tolak ukur bagi peneliti yang akan meneliti variabel lain yang berhubungan kejadian kusta.

2. Bagi penderita kusta

Penderita kusta diharapkan mampu melakukan perawatan diri secara rutin setiap hari, dan cek- up ke pelayanan kesehatan sesuai anjuran yaitu setiap bulan.

3. Bagi masyarakat

Hasil penelitian ini diharapkan dapat memberikan motivasi masyarakat untuk lebih aktif lagi dalam mengikuti kegiatan sosialisasi yang sering diadakan oleh petugas kesehatan.

4. Bagi tenaga kesehatan

Melakukan sosialisasi tentang cara perawatan diri terhadap penderita kusta dan keluarga penderita untuk mencegah terjadi kecacatan serta mencegah kecacatan yang sudah ada agar tidak bertambah parah.

5. Bagi Institusi Pendidikan

Keperawatan Dapat dijadikan sebagai tambahan pustaka dalam bidang ilmu pengetahua serta sebagai tambahan refrensi bacaan tentang pengetahuan tentang kusta (Leprosy) dan perawatan diri pada pemderita kusta

\section{DAFTAR PUSTAKA}

Amirudin M. 2012. Penyakit Kusta Sebuah Pendekatan Klinis. Brilian Internasional: Surabaya.

Andy M. 2014. Faktor risiko kejadian kusta tahun 2006-2007. Jurnal. Sekolah Tinggi Ilmu Kesehatan Kuningan. Di publikasi.

Agustina dkk, 2013. Hubungan Pengetahuan dan Sikap Keluarga dengan Tingkat Kecacatan pada Penderita Kusta di Kabupaten Padang Pariaman Tahun 2013. Jurnal kesehatan andalas.

Depkes RI. 2006. Buku Pedoman Nasional Pe mbera-ntasan Penyakit, kusta, Cetakan XVII, Direktorat Jendral PPM dan PLP, Jakarta.

Dewi, dkk. 2015. Deterrminan kejadian kusta di Wilayah Kerja Puskesmas Kecamatan Lino tahun 2013.

Dinkes Provinsi Nusa Tenggara Timur. Profil kesehatan NTT, 2015.

Silvia I .2014. Faktor risiko yang berhubungandengan kejadian kusta (studi kasus di wilayah kerja puskesmas kunduran blora. Skripsi: Universitas Negeri Semarang April 2014

Catrina, dkk. 2016. Faktor-faktor yang berhubungan dengan tingkat 
kecacatan klien kusta Kelurahan

Bitahan RT 11 dan 12 Wilayah kerja

Puskesmas Lokpaikat tahun 2015.

Kemenkes. 2014. Pedoman Nasional Program

Pengendalian Penyakit Kusta, Jakarta:

Direktorat Jenderal Pengendalian

Penyakit dan Penyehatan Lingkungan.

Kemenkes. 2015. 25 januari hari kusta sedunian, Jakarta: Pusat Data dan Informasi Kementrian dan Kesehatan RI.

Kemenkes RI. Profil Kesehatan Indonesia, 2015.

Kemenkes RI. 2016. Profil kesehatan Indonesia 2015.

Lia Setiani. 2014. Faktor-faktor yang berhubungan dengan kejadian kusta Di Wilayah Kerja puskesmas kabunan kabupaten pemalang tahun 2014. Artikel: Universitas Muhammadiyah Surakarta.

Linda. dkk, 2004. Panduan Pencegahan Infeksi. Jakarta: Yayasan Bina Pustaka Sarwono Prawirohardjo.

Marwali Harahap. 2000, Ilmu Penyakit Kulit, Jakarta: Hipokrates.

Puskemas bakunase Kota Kupang. Profil Puskesmas Bakunase Kota Kupang, 2015.

Ramadhan Tosepu dkk. 2015. Epidemiology study of leprosy patients in the district of Bombana Southeast Sulawesi Province, Indonesia. International Journal of Research in Medical Sciences. Int J Res

\section{Med Sci. 2015}

Riyanto Martomijoyo. 2012. Faktor-faktor yang mempengaruhi kejadian penyakit kusta pada penduduk di kecamatan tukdana Kabupaten indramayu tahun 2012. Jurnal Vol.VII No. 11 April 2014

Robin G. 2005, Dermatologi, Jakarta: Erlangga.

Soekidjo Notoatmodjo. 2005, Promosi Kesehatan Teori dan Aplikasi, Jakarta: Rineka Cipta

Sudigdo S, Sofyan I. 2002, Dasar-Dasar Metodologi Klinis Edisi ke-2, Jakarta: Binarupa Aksara.

Sugiyono. 2009. Metode Penelitian Kuantitatif dan Kualitatif Dan R\&D. Bandung: Alfabeta.

Tamsuri A. 2010. Hubungan pengetahuan dan perilaku pencegahan penularan penyakit kusta di Wilayak Kerja Puskesmas Tangunganom Kabupaten Nganjuk Tahun 2008.

Yessita. 2013. Faktor yang berhubungan dengan kejadian kusta di Wilayah Kerja Puskesmas Gunem dan Sarang Kabupaten Pemalang tahun 2011.

Yudied dkk. 2008, Kajian Pengendalian Potensial Faktor Risiko Penularan Penyakit Kusta dan Intervensinya di Puskesmas Pragaan Kabupat en Sumenep Tahun 2007, Buletin Human Media Volume 03 Nomor 03 September 2008.

Ready to submit your research? Choose INFOKES and benefit from:

- fast, convenient online submission

- thorough peer review by experienced researchers in your field

- $\quad$ rapid publication on acceptance

- $\quad$ support for research data

- $\quad$ Open Access which fosters wider collaboration and increased citations

- maximum visibility for your research

At Health Polytechnic of Kupang, research is always in progress.

Learn more http://jurnal.poltekkekupang.ac.id/index.php/infokes 